\section{National Produce Market Barrier Penetration: The Georgia Case}

\author{
J.E. Epperson, ${ }^{1}$ P.D. McPherson, and F.E. Stegelin \\ Department of Agricultural and Applied Economics, University of Georgia, \\ 301 Conner Hall, Athens, GA 30602
}

Additional index words. barriers to entry, penetration factors, fruit, vegetables

\begin{abstract}
This study examined factors contributing to the development of the produce industry in Georgia and means of overcoming barriers to entry into the national fresh fruit and vegetable market. A survey of produce growers in Georgia was conducted in 2003-04. Information obtained from the respondents included economic and operational characteristics of grower enterprises and more specifically factors limiting production, expected operational changes, and marketing practices. Grower tendencies were ascertained from survey responses with respect to sales using regression analysis. Factors found important in overcoming barriers to national market entry stem from the degree of specialization and sophistication of producers.
\end{abstract}

Several factors have been linked to the growth of the produce industry in Georgia. A major contributor has been urban encroachment resulting in the loss of vast areas of agricultural land in Florida (Lockette, 2004; Reynolds, 2001). As with North Florida, South Georgia has a mild climate suitable for growing produce, but unlike Florida, is sparsely populated (Bauer et al., 1989; Boatright and Bachtel, 2004; Epperson and Lei, 1989; Epperson and Tyan, 1984). Another factor boosting growth has been the tremendous increase in demand for produce in the United States (U.S. Department of Agriculture, 2005). In recent years, the increased popularity of precut vegetables and the growth in the variety of vegetables has contributed to the expansion in vegetable consumption (Estes and Smith, 1996).

Though the produce industry has grown in Georgia, greater advances are possible. The data will show that many producers face barriers to the national produce market, which if overcome, could proffer even greater growth in the industry. The purpose of this study is to examine factors linked to success in the produce industry in Georgia and to find ways to overcome barriers to entry into the national market.

\section{Materials and Methods}

Asurvey of commercial fruit and vegetable growers in Georgia was conducted in 2003-04. Total enumeration was attempted of producers included in the Georgia Fruit and Vegetable Directory (Georgia Department of Agriculture, 2003) in addition to producers who earned more than half of farm income from produce sales as identified by county Extension directors in the top 10 fruit and vegetable producing counties

Received for publication 6 Oct. 2005. Accepted for publication 27 Jan. 2006. This research was funded by the USDA/CSREES/IFAFS as part of a joint project involving the University of Georgia, University of Kentucky, North Carolina State University, and University of Tennessee.

${ }^{1}$ To whom reprint requests should be addressed; e-mailepperson@uga.edu.
(Boatright and McKissick, 2003). The survey was distributed by mail and followed up by phone and personal interviews. A total of 300 surveys were distributed (220 from directory listings plus 80 supplemented by county Extension directors) with 65 completed, for a response rate of $22 \%$. Information obtained from the respondents included economic and operational characteristics of grower enterprises and more specifically factors limiting production, expected operational changes, and marketing practices.

Linear regression was used to conduct the analysis. The statistical model is given as: $Y=\alpha+\beta_{1} X_{1}+\beta_{2} X_{2}+\ldots+\beta_{n} X_{n}$, where $\alpha$ is the intercept, $\beta_{\mathrm{n}}$ are the regression coefficients, $X_{n}$ represent the independent variables, and $\mathrm{Y}$ represents the dependent variable. Because the data are cross sectional, White's (1980) heteroskedasticity-consistent matrix was employed to correct estimates for any unknown form of heteroskedasticity.

The dependent variable used in the analysis is sales from produce, SALES, an important indicator of success. Numerical values assigned for each sales category are as follows: $1=$ under $\$ 20,000,2=\$ 20,000$ to $\$ 49,999,3=\$ 50,000$ to $\$ 99,999,4=\$ 100,000$ to $\$ 249,999,5=$ $\$ 250,000$ to $\$ 499,999$, and $6=\$ 500,000$ or more. Because of the great number of potential explanatory variables (some 170), a preliminary investigation using cross tabulation was conducted to narrow the scope of independent variables to a manageable level. Selected variables are those that appeared to be associated with sales. Put differently, the selected variables are produce operation characteristics expected to be positive or negative indicators of success. Definitions of the 17 independent variables included in the model are provided in Table 1. Simple statistics for the variables, including mean, SD, and minimum and maximum values, are provided in Table 2 . The parameter estimates, $t$ values, and significance levels for the model are presented in Table 3 . The $R^{2}$ value of 0.77 and the $\mathrm{F}$ value of 9.17 with $P$ $<0.0001$ provide evidence that the model fits the cross-section data well.
The coefficients for several variables were found to be significant and positive with respect to produce sales, Table 3 . These variables included years of experience growing produce (YEAREXPR), using the Georgia Department of Agriculture (GADEPTAG) as a source of production information, summer squash [Cucurbita moschata (Duchesne ex Lam.) Duchesne ex Poir.] land area (SMSQUASH), pest control (PEST) impact on production expansion, broker/wholesaler as marketing information source (BWMKINFO), the importance of buyer-seller relationships (BSREL) for new crop considerations, and operations that pack produce (PACKPRDC).

The coefficients of four variables were found to be significant and negative with respect to produce sales, Table 3 . These variables included using the Farm Service Agency (FSA) of the USDA as a source of production information, watermelon [Citrullus lanatus (Thunb.) Matsumura \& Nakai] land area (WTRMELON), no source for marketing information (NOMKINFO), and the importance of market location (MKTLOC) for new crop considerations.

Experience growing produce (YEAREXPR) is shown to be extremely important for higher sales. Apparently, at some point, with increasing experience, a transition is possible from a direct-market orientation with limited volume potential to a national market focus via market intermediaries and chain-store buyers - the reward for tenacity. Larger producers were the main users of the Georgia Department of Agriculture (GADEPTAG) as a source of production information. Larger producers tend to participate in produce grower meetings where the Department of Agriculture has a large presence. Networking with personnel from the Department of Agriculture can lead to contacts with intermediaries for the national market. Farm Service Agency (FSA) programs are geared toward smaller producers. When small producers consider alternative enterprises such as fruit and vegetables, it seems natural that they would seek information from established contacts such as FSA personnel.

Summer squash (SMSQUASH) requires great care in growing and post-harvest handling due to its delicate nature. Summer squash is representative of the kinds of delicate produce grown by sophisticated producers with national distribution connections and relatively higher sales. Watermelon production(WTRMELON) is indicative of the kinds of crops that are convenient for small scale producers with relatively lower sales. Watermelon can be easily transported in truckload lots without costly packing to direct-market outlets. Pest control (PEST) is expensive and of critical importance in the production of unblemished produce for the national market. Because of costs and regulations, pest control was found to be a constraining factor on expansion by larger producers with relatively higher sales. Those that identified broker or wholesaler as a source of marketing information(BWMKINFO) tended to be larger producers who characteristically have busi- 
Table 1. Independent variables included in model.

\begin{tabular}{|c|c|c|c|c|}
\hline Variable & & \multicolumn{3}{|c|}{ Definition } \\
\hline YEAREXPR & & \multicolumn{3}{|c|}{ Years experience growing produce commercially (1 = } \\
\hline GADEPTAG & & \multicolumn{3}{|c|}{ State Dept. of Agriculture source of production infor } \\
\hline FSA & & \multicolumn{3}{|c|}{ Farm Service Agency source of production informati } \\
\hline SMSQUASH & & \multicolumn{3}{|c|}{ Land area in summer squash (units of $0.40 \mathrm{ha}$ ) } \\
\hline WTRMELON & & \multicolumn{3}{|c|}{ Land area in watermelon (units of $0.40 \mathrm{ha}$ ) } \\
\hline PEST & & \multicolumn{3}{|c|}{ Pest control impact on expansion $(1=$ not limiting $\ldots$} \\
\hline NEW & & \multicolumn{3}{|c|}{ Try new cultivars $(1=$ yes, $0=$ no $)$} \\
\hline DRCTMKT & & \multicolumn{3}{|c|}{ Percentage of produce sales direct marketed } \\
\hline HIRESRVC & & \multicolumn{3}{|c|}{ Use labor hiring service $(1=$ yes, $0=$ no $)$} \\
\hline RISK & & \multicolumn{3}{|c|}{ Risk is deciding factor in production $(1=$ yes, $0=$ no } \\
\hline BWMKINFO & & \multicolumn{3}{|c|}{ Broker/wholesaler marketing source $(1=$ yes, $0=$ no $)$} \\
\hline NOMKINFO & & \multicolumn{3}{|c|}{ No marketing source $(1=$ yes, $0=$ no $)$} \\
\hline MKTLOC & & \multicolumn{3}{|c|}{ Market location consideration for new crop $(1=$ not $\mathrm{i}$} \\
\hline BSREL & & \multicolumn{3}{|c|}{ Buyer-seller relationship consideration for new crop } \\
\hline PACKPRDC & & \multicolumn{3}{|c|}{ Pack produce $(1=$ yes, $0=$ no $)$} \\
\hline USEBKR & & \multicolumn{3}{|c|}{ Outsource selling function $(1=$ yes, $0=$ no $)$} \\
\hline TRACEBAC & & \multicolumn{3}{|c|}{ Believe traceback will impact operation in next few y } \\
\hline Variable & Mean & SD & Min & Max \\
\hline YEAREXPR & 3.40 & 0.93 & 1.0 & 4.0 \\
\hline GADEPTAG & 0.18 & 0.39 & 0.0 & 1.0 \\
\hline FSA & 0.12 & 0.33 & 0.0 & 1.0 \\
\hline SMSQUASH & 10.88 & 41.12 & 0.0 & 275.0 \\
\hline WTRMELON & 2.90 & 6.12 & 0.0 & 26.0 \\
\hline PEST & 1.82 & 1.04 & 1.0 & 5.0 \\
\hline NEW & 0.66 & 0.48 & 0.0 & 1.0 \\
\hline DRCTMKT & 42.66 & 40.37 & 0.0 & 100.0 \\
\hline HIRESRVC & 0.17 & 0.38 & 0.0 & 1.0 \\
\hline RISK & 0.25 & 0.43 & 0.0 & 1.0 \\
\hline BWMKINFO & 0.71 & 0.46 & 0.0 & 1.0 \\
\hline NOMKINFO & 0.06 & 0.24 & 0.0 & 1.0 \\
\hline MKTLOC & 3.82 & 1.18 & 1.0 & 5.0 \\
\hline BSREL & 3.89 & 1.11 & 1.0 & 5.0 \\
\hline PACKPRDC & 0.72 & 0.45 & 0.0 & 1.0 \\
\hline USEBKR & 0.25 & 0.43 & 0.0 & 1.0 \\
\hline TRACEBAC & 0.38 & 0.49 & 0.0 & 1.0 \\
\hline SALES & 3.18 & 1.87 & 1.0 & 6.0 \\
\hline
\end{tabular}

Table 3. Model parameter estimates and $t$ values.

\begin{tabular}{lcr}
\hline Variable & $\begin{array}{c}\text { Parameter } \\
\text { estimate }\end{array}$ & $\begin{array}{r}t \\
\text { value }\end{array}$ \\
\hline INTERCEPT & $-1.19^{\mathrm{NS}}$ & -1.31 \\
YEAREXPR & $0.60^{* * * *}$ & 3.98 \\
GADEPTAG & $0.84^{* *}$ & 3.00 \\
FSA & $-0.87^{* * *}$ & -3.40 \\
SMSQUASH & $0.01^{* *}$ & 2.74 \\
WTRMELON & $-0.06^{* *}$ & -2.63 \\
PEST & $0.46^{* * *}$ & 3.75 \\
NEW & $0.45^{\mathrm{NS}}$ & 1.25 \\
DRCTMKT & $-0.00^{\mathrm{NS}}$ & -0.32 \\
HIRESRVC & $-0.16^{\mathrm{NS}}$ & -0.61 \\
RISK & $0.35^{\mathrm{NS}}$ & 1.20 \\
BWMKINFO & $0.59^{*}$ & 2.08 \\
NOMKINFO & $-1.67^{* * *}$ & -3.68 \\
MKTLOC & $-0.52^{* * *}$ & -6.54 \\
BSREL & $0.47^{* * *}$ & 4.56 \\
PACKPRDC & $1.26^{* * *}$ & 4.33 \\
USEBKR & $0.43^{\mathrm{NS}}$ & 1.44 \\
TRACEBAC & $0.44^{\mathrm{NS}}$ & 1.23 \\
$R^{2}$ & 0.77 & \\
df & 47 & \\
F & 9.17 & \\
\hline NS ${ }^{* * * * * * *}$ Nonsignificant & or significant at $P \leq 0.05$, \\
0.01, or 0.001, respectively. &
\end{tabular}

ness relationships with these national market intermediaries. Producers who use no source of marketing information (NOMKINFO) operate without full information and tend to have less produce sales. Larger producers used one or more sources to obtain marketing informa- tion. Large-scale producers are connected to market intermediaries, shipping nationally and beyond. Thus, market location (MKTLOC) is more important to smaller operations using direct-market outlets. Buyer-seller relationships (BSREL) for new crop considerations were more important to larger operations. Producing the desired commodity in sufficient volume with excellent timing is extremely important to national market intermediaries.

Packing produce (PACKPRDC) for the national market requires capital and labor for assembly-line operations. Thus, packing sheds are expensive, complex, and typically limited to larger operations with relatively higher sales. In tabular analysis, this aspect was shown to be positively skewed to larger operations, with just under half of the respondents in the smallest class (under \$20,000) and all of those in the largest class ( $\$ 500,000$ or more) packing produce. Smaller producers place produce in containers or truckload lots for transport to local farmers' markets, roadside stands, or packing sheds.

The grower and operational characteristics found to be important with respect to level of sales from produce can be traced to degree of specialization in the produce operation. The degree of specialization goes hand in hand with level of sophistication in production, postharvest handling, quality control, and marketing.
The two produce items found important, summer squash and watermelons, are representative of the stark differences in sophistication between small and large produce operations. Large volumes of a delicate commodity like summer squash require highly specialized production and postharvest handling methods, while commodities like watermelon require less intensive management, can be transported in bulk, and have a relatively long shelf life. Typically only the larger operations are equipped to produce and handle commodities requiring sophistication and specialization.

Another major difference between small and large operators pertained to information sources. Brokers and wholesalers were found to be important sources of marketing information especially to larger producers. Clearly, established contacts with national market intermediaries are highly advantageous.

Surprisingly, there were producers, all of whom had small operations, who did not have a source of marketing information. Certainly, it is difficult to be competitive without full information.

Small volume producers, for the most part, use direct-market outlets. The majority of these smaller producers harvest and transport produce directly to the local farmers' market or roadside stand for sale.

The finding that the Georgia Department of Agriculture was an important source of production information for large produce growers may, indeed, indicate an effectual avenue of transition for small, but enterprising producers. The Department of Agriculture typically has a large presence at produce grower meetings and conferences which are widely attended by large producers. Moreover, the Department of Agriculture provides facilities to market intermediaries at strategic locations in the state. Thus, the opportunities for networking at grower meetings and conferences with large producers and Department of Agriculture personnel who have contacts with market intermediaries are limited only by personal initiative. To gain entry into the national market, producers must learn highly specialized and sophisticated production and postharvest handling methods and must come in contact with market intermediaries and chain buyers. Indications are that grower meetings and conferences are fertile grounds 
for establishing inroads to the national market and beyond.

In summary, the profile of a successful grower who produces for the national fruit and vegetable market includes the following: has many years of experience; uses production information and networks via the State Department of Agriculture (in Georgia), largely at grower meetings and conferences; grows produce requiring specialized and sophisticated production and postharvest handling methods; uses state-of-the-art pest management techniques which are more difficult to manage with expansion; values marketing information from market intermediaries; prizes buyer-seller relationships when considering new crops; and grades and packs for the national market.

\section{Literature Cited}

Bauer, L.L., J.E. Epperson, J.T. Garrett, and D.C.
Sanders. 1989. The South Atlantic Coast vegetable project: a multistate team approach to research on alternative farming opportunities. HortScience 24:534, 723.

Boatright, S.R., and D.C. Bachtel. 2004. Georgia county guide. Univ. Ga. Ctr. for Agribusiness and Econ. Dev.

Boatright, S.R., and J.C. McKissick. 2004. 2003 Georgia farm gate value report. Univ. Ga. Ctr. Agribusiness and Econ. Dev. AR 04-01. http:// www.agecon.uga.edu/\%7Ecaed/2003fgvr.pdf .

Epperson, J.E., and H.L. Tyan. 1984. An examination of market potential in regional fresh-produce markets: the Georgia case. Ga. Agr. Expt. Sta. Res. Bul. 314

Epperson, J.E. and L.F. Lei. 1989. Aregional analysis of vegetable production with changing demand for row crops using quadratic programming. Southern J. Agr. Econ. 21(1):87-96.

Estes, E., and K. Smith. 1996. Price, quality, and pesticide related health risk considerations in fruit and vegetable purchases: A hedonic analysis of Tucson, Arizona, supermarkets. J. Food Distrib.
Res. 27(2):60-76.

Georgia Department of Agriculture. 2003. Georgia fruit and vegetable directory. Ga. Dept. Agr., Atlanta.

Lockette, T. 2004. Development to cost Florida almost 3 million acres of rural land by 2020 , UF expert warns. Univ. Fla. Inst. Food and Agr. Sci. News. Univ. Fla., Gainesville. 17 Mar. 2004. http://news.ifas.ufl.edu/archives. php?year=2004.

Reynolds, J.E. 2001. Urbanization and land use change in Florida and the South, p. 28-49. In:

Current issues associated with land values and land use planning: proceedings of a regional workshop. Southern Reg. Dev. Ctr. Ser. 220. http:// srdc.msstate.edu/publications/series.htm.

U.S. Department of Agriculture. 2005. ERS/USDA data-Food consumption (per capita) data system. http://www.ers.usda.gov/Data/foodconsumption/.

White, H. 1980. A heteroskedasticity-consistent covariance matrix estimator and a direct test for heteroskedasticity. Econometrica 48(4):817-838. 